\title{
Seismic Evaluation of Reinforced Concrete Frames in the Harsh Environment Using Pushover Analysis
}

\author{
Mohamed Sobaih'1, Ahmed Al Ghazali² \\ ${ }^{1}$ Department of Structural Engineering, Cairo University, Gize, Egypt \\ ${ }^{2}$ Institute of Construction Materials, Faculty of Civil Engineering, TU Dresden, Dresden, Germany \\ Email: msobaih2@yahoo.com, ahmed.al_ghazali@tu-dresden.de
}

How to cite this paper: Sobaih, M. and $\mathrm{Al}$ Ghazali, A. (2016) Seismic Evaluation of Reinforced Concrete Frames in the Harsh Environment Using Pushover Analysis. Open Journal of Civil Engineering, 6, 685696.

http://dx.doi.org/10.4236/ojce.2016.64055

Received: August 18, 2016

Accepted: September 27, 2016

Published: September 30, 2016

Copyright $\odot 2016$ by authors and Scientific Research Publishing Inc. This work is licensed under the Creative Commons Attribution International License (CC BY 4.0).

http://creativecommons.org/licenses/by/4.0/

\section{Abstract}

The main objective of this paper is to evaluate the seismic response of buildings of typical reinforced concrete frames when concrete starts to deteriorate gradually and to make a comparison between the base shear and the displacement at different stages of earthquake loading. Typical 5, 15, 20 and 30-storey reinforced concrete frames have been designed for seismicity according to the recently adopted seismic code in Abu Dhabi, ACI 318-08/IBC 2009 code. A pushover analysis has been performed to these four buildings by using SAP 2000. Twenty-four models have been created (6 models for each building) by decreasing the concrete strength gradually from 4000 psi $\left(281 \mathrm{~kg} / \mathrm{cm}^{2}\right)$ to $1500 \mathrm{psi}\left(105 \mathrm{~kg} / \mathrm{cm}^{2}\right)$. This is to simulate the effect of harsh environment on the strength of concrete in existing buildings.

\section{Keywords}

Pushover Analysis, ACI 318-08/IBC 2009, Abu Dhabi, Harsh Environment

\section{Introduction}

It is well known that Abu Dhabi has witnessed seismic activities in recent years. Besides, the design of buildings in Abu Dhabi did not take into consideration the effect of earthquakes until 1997. It is expected that larger stock of existing buildings in Abu Dhabi is at risk due to the combined effect of the harsh environment and expected earthquake activity, so analytical model is needed to find out the effect of the harsh environment or concrete deterioration on the existing buildings in Abu Dhabi. Abu Dhabi is located in the Arabian Gulf region which is well known for its harsh environment. The city of Abu Dhabi has witnessed an extensive urbanization development during the 
last three decades and the concrete has been the most widely used construction material. It is well known that the prevailing harsh environment in Abu Dhabi leads to lower strength of concrete with time. Figure 1 shows concrete deterioration by time.

\section{General Description of Studied Cases}

Four two-bay frame models are used to represent typical construction of buildings in Abu Dhabi and designed according to ACI 318-08 [1] and IBC 2009 [2] building codes. The typical bay width and story height of the frame model are 5.0 and $3.0 \mathrm{~m}$, respectively. The ground floor height is $5.0 \mathrm{~m}$ to take into account the foundation depth. Since Abu Dhabi is located in the Arabian Gulf region the common soils in Abu Dhabi are generally classified as weak soils, and hence, the buildings are usually founded on piles. The four models neglected the effect of torsion in buildings subjected to earthquakes assuming that the center of mass of the building coincides with the center of rigidity of its columns. The selected numbers of stories of RC buildings considered are 5 , 15, 20 and 30 storeys. Figure 2 represents one of them.

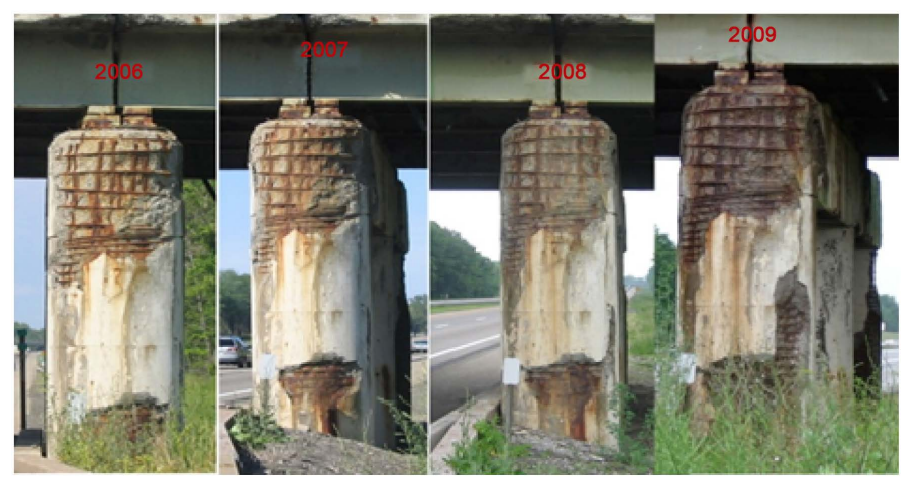

Figure 1. Concrete deterioration by time.

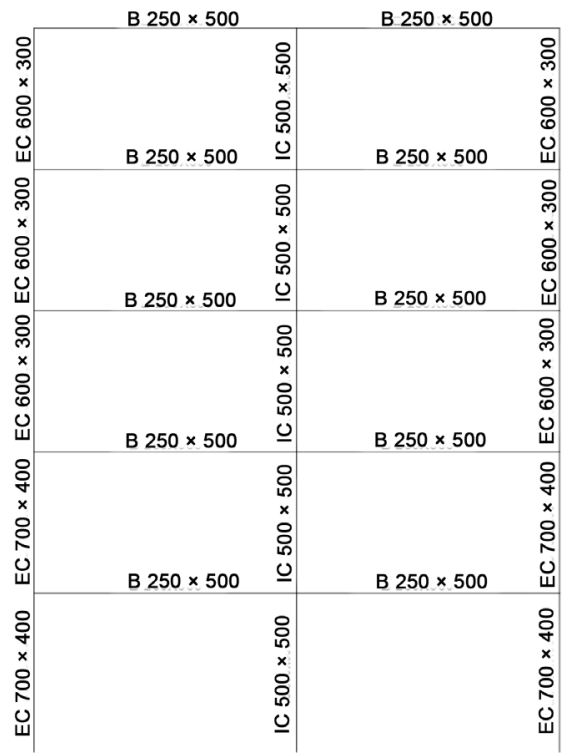

Figure 2. Five-storey building beams and columns sections. 


\section{Beams Design}

The beam section is designed for the maximum positive and maximum negative factored moment envelopes obtained from all of the load combinations, negative beam moments produce top steel while as positive beam moments produce bottom steel. Table 1 shows the beams cross sections that are used in the fifteen stories model and the corresponding steel reinforcement. The design has been done by using SAP 2000 [3].

\section{Columns Design}

In the design of columns, external columns were designed as rectangular sections and internal columns were designed as square sections as shown in Table 2. In this table "EC" indicates External column and "IC" indicates internal column. The cover in all columns is $0.04 \mathrm{~m}$ and the spacing between the stirrups is $0.15 \mathrm{~m}$. Table 2 shows the column sections that are used in the fifteen stories model, area of main steel and bar sizes for the main steel and the stirrups.

\section{Results}

After designing and detailing the reinforced concrete frame structures, a nonlinear pushover analysis is carried out for evaluating the structural seismic response. The pushover analysis consists of the application of gravity loads and a representative lateral load pattern. The lateral loads were applied monotonically in a step-by-step nonlinear static analysis. The applied lateral loads were accelerations in the $\mathrm{x}$ direction representing the forces that would be experienced by the structures when subjected to

Table 1. Five-storey design for beams sections.

\begin{tabular}{ccccccc}
\hline \multirow{2}{*}{$\begin{array}{c}\text { Section } \\
\text { Name }\end{array}$} & $\begin{array}{c}\text { Top } \\
\text { Cover }\end{array}$ & $\begin{array}{c}\text { Bot } \\
\text { Cover }\end{array}$ & $\begin{array}{c}\text { Area of } \\
\text { Steel Top }\end{array}$ & $\begin{array}{c}\text { Final } \\
\text { Reinforcement Top }\end{array}$ & $\begin{array}{c}\text { Area of Steel } \\
\text { Bot }\end{array}$ & $\begin{array}{c}\text { Final } \\
\text { Reinforcement Bot }\end{array}$ \\
\cline { 2 - 7 } B250X500_1 & 0.04 & 0.04 & 770 & $5 \mathrm{~T} \mathrm{14}$ & 452 & $4 \mathrm{~T} \mathrm{12}$ \\
B250X500_2 & 0.04 & 0.04 & 770 & $5 \mathrm{~T} \mathrm{14}$ & 452 & 4 T 12 \\
B250X500_3 & 0.04 & 0.04 & 770 & $5 \mathrm{~T} \mathrm{14}$ & 565 & 5 T 12 \\
B250X500_4 & 0.04 & 0.04 & 770 & $5 \mathrm{~T} \mathrm{14}$ & 452 & 4 T 12 \\
B250X500_5 & 0.04 & 0.04 & 565 & $5 \mathrm{~T} \mathrm{12}$ & 393 & 5 T 10 \\
\hline
\end{tabular}

Table 2. Five-storey design for columns sections.

\begin{tabular}{cccccccc}
\hline Section Name & $\begin{array}{c}\text { Num Bars } \\
\text { 3 Dir }\end{array}$ & $\begin{array}{c}\text { Num Bars } \\
\text { 2 Dir }\end{array}$ & $\begin{array}{c}\text { Bar Size } \\
\text { Main }\end{array}$ & $\begin{array}{c}\text { Area } \\
\text { of Steel } \\
\mathrm{mm}^{2}\end{array}$ & $\begin{array}{c}\text { Final } \\
\text { Reinforcement }\end{array}$ & $\begin{array}{c}\text { Bar Size } \\
\text { Stirrup }\end{array}$ & $\begin{array}{c}\text { Spacing } \\
\text { Stirrup } \\
\mathrm{m}\end{array}$ \\
\hline EC600X300 & 4 & 4 & $14 \mathrm{~d}$ & 1848 & $12 \mathrm{~T} 14$ & $10 \mathrm{~d}$ & 0.15 \\
EC700X400 & 3 & 6 & $16 \mathrm{~d}$ & 2814 & $14 \mathrm{~T} 16$ & $10 \mathrm{~d}$ & 0.15 \\
IC500X500 & 3 & 3 & $20 \mathrm{~d}$ & 2512 & $8 \mathrm{~T} 20$ & $10 \mathrm{~d}$ & 0.15 \\
\hline
\end{tabular}


ground shaking. Under incrementally increasing loads some elements may yield sequentially. Consequently, at each event, the structures experience a stiffness change as shown in Figure 3, where IO, LS and CP stand for immediate occupancy, life safety and collapse prevention, respectively

\subsection{Pushover Curves for Reinforced Concrete Frame}

Six different concrete strengths were used in the analysis: 4000 psi, 3500 Psi, 3000 psi, 2500 psi, 2000 psi and 1500 psi. Each concrete strength was used with the four different reinforced concrete building heights 5, 15, 20 and 30 stories. The base shear versus the lateral displacement of the top floor (pushover curve) is plotted for each frame.

\section{Pushover Curves for 5-Stories Building}

By using IBC 2009 Code and decreasing the concrete strength from 4000 psi (281 $\left.\mathrm{kg} / \mathrm{cm}^{2}\right), 3500 \mathrm{psi}\left(246 \mathrm{~kg} / \mathrm{cm}^{2}\right), 3000$ psi $\left(211 \mathrm{~kg} / \mathrm{cm}^{2}\right), 2500 \mathrm{psi}\left(176 \mathrm{~kg} / \mathrm{cm}^{2}\right), 2000 \mathrm{psi}$ $\left(141 \mathrm{~kg} / \mathrm{cm}^{2}\right), 1500 \mathrm{psi}\left(105 \mathrm{~kg} / \mathrm{cm}^{2}\right)$ in the model, push over curves are obtained as shown in Figures 4-6 for 5 Stories reinforced concrete building.

The displacement and the base shear values at the three deformation points Immediate Occupancy (IO), Life Safety (LS), Collapse Prevention (CP) and initial failure "D" can be obtained from the pushover analysis curves as shown in Tables 3-8.

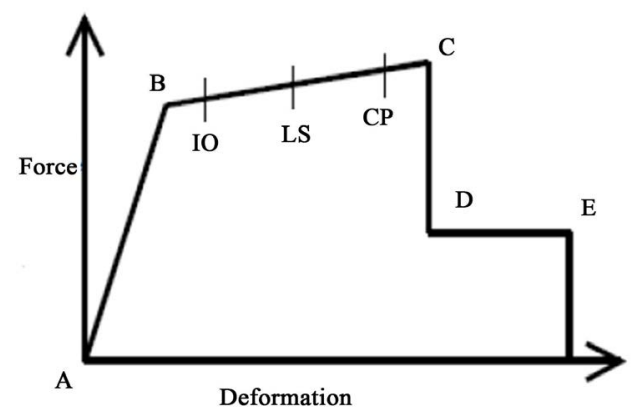

Figure 3. Load deformation curve [4].

Table 3. Pushover curve main values for 5-storey building using 4000 psi.

\begin{tabular}{ccccc}
\hline & IO & LS & CP & Initial Failure "D" \\
\hline Displacement $(\mathrm{m})$ & 0.126595 & 0.288625 & 0.372025 & 1.2558 \\
Base Shear $(\mathrm{kN})$ & 321.559 & 339.2927 & 345.8679 & 189.570 \\
\hline
\end{tabular}

Table 4. Pushover curve main values for 5-storey building using 3500 psi.

\begin{tabular}{ccccc}
\hline & IO & LS & CP & Initial Failure “D” \\
\hline Displacement $(\mathrm{m})$ & 0.13447 & 0.2795 & 0.3628 & 1.3059 \\
Base Shear $(\mathrm{kN})$ & 318.267 & 334.752 & 341.337 & 184.517 \\
\hline
\end{tabular}

Table 5. Pushover curve main values for 5-storey building using 3000 psi.

\begin{tabular}{ccccc}
\hline & IO & LS & CP & Initial Failure “D” \\
\hline Displacement $(\mathrm{m})$ & 0.123 & 0.2322 & 0.4011 & 1.3754 \\
Base Shear $(\mathrm{kN})$ & 308.364 & 325.907 & 337.133 & 176.980 \\
\hline
\end{tabular}


Table 6. Pushover curve main values for 5-storey building using 2500 psi.

\begin{tabular}{ccccc}
\hline & IO & LS & CP & Initial Failure “D” \\
\hline Displacement $(\mathrm{m})$ & 0.1365 & 0.2892 & 0.3527 & 1.4612 \\
Base Shear $(\mathrm{kN})$ & 302.191 & 322.916 & 327.725 & 163.259 \\
\hline
\end{tabular}

Table 7. Pushover curve main values for 5-storey building using 2000 psi.

\begin{tabular}{ccccc}
\hline & IO & LS & CP & Initial Failure "D" \\
\hline Displacement $(\mathrm{m})$ & 0.1296 & 0.2723 & 0.3455 & 1.5742 \\
Base Shear $(\mathrm{kN})$ & 286.699 & 312.16 & 317.556 & 143.314 \\
\hline
\end{tabular}

Table 8. Pushover curve main values for 5-storey building using 1500 psi.

\begin{tabular}{ccccc}
\hline & IO & LS & CP & Initial Failure “D” \\
\hline Displacement $(\mathrm{m})$ & 0.1246 & 0.2625 & 0.3369 & 1.7261 \\
Base Shear $(\mathrm{kN})$ & 267.699 & 301.346 & 303.549 & 123.393 \\
\hline
\end{tabular}
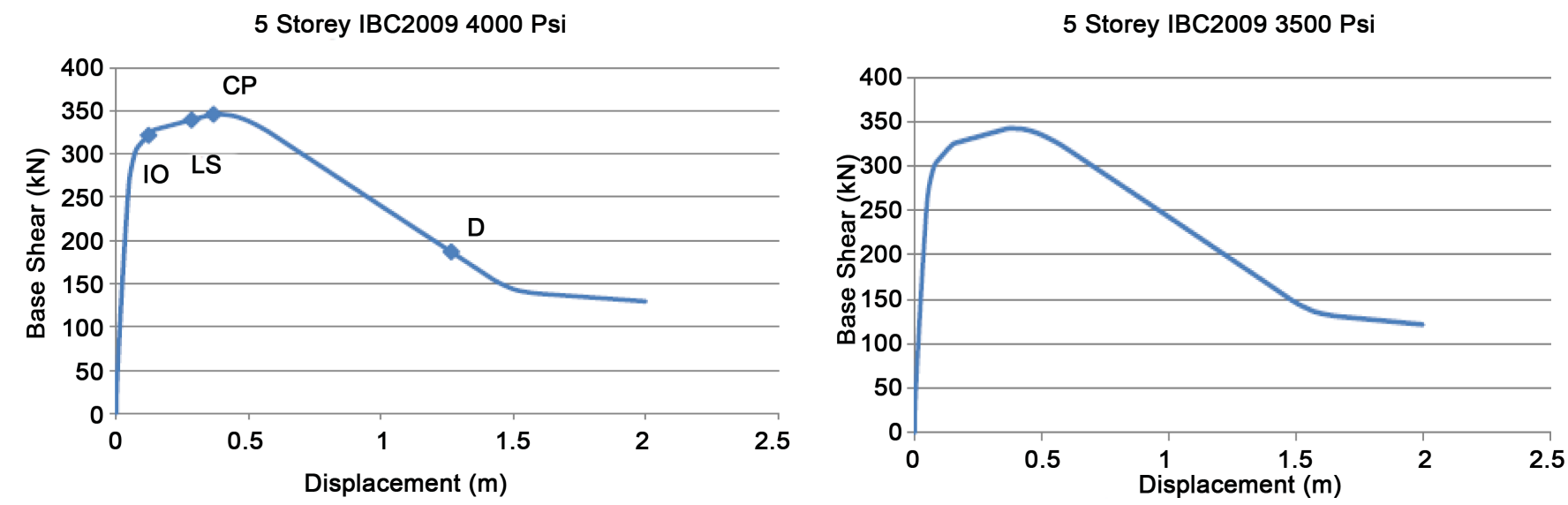

Figure 4. Pushover curve for 5-storey building using 4000 and 3500 psi concrete strength.

5 Storey IBC2009 3000 Psi

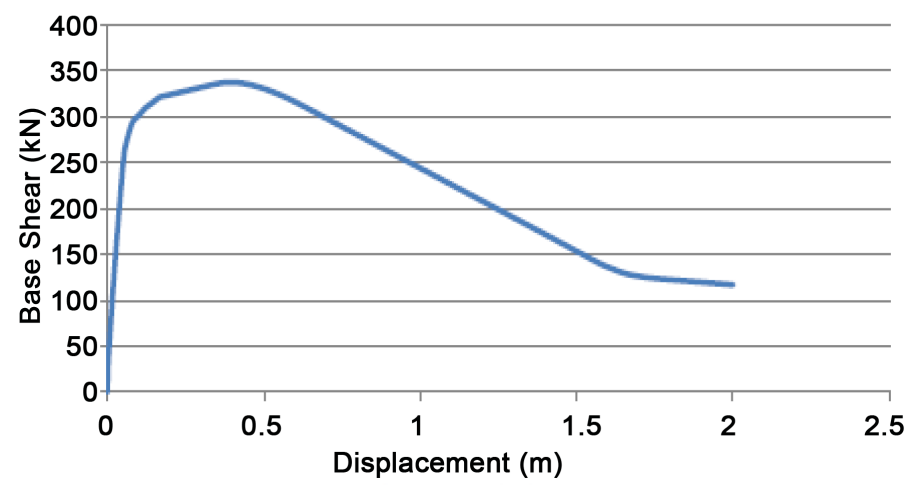

5 Storey IBC2009 2500 Psi

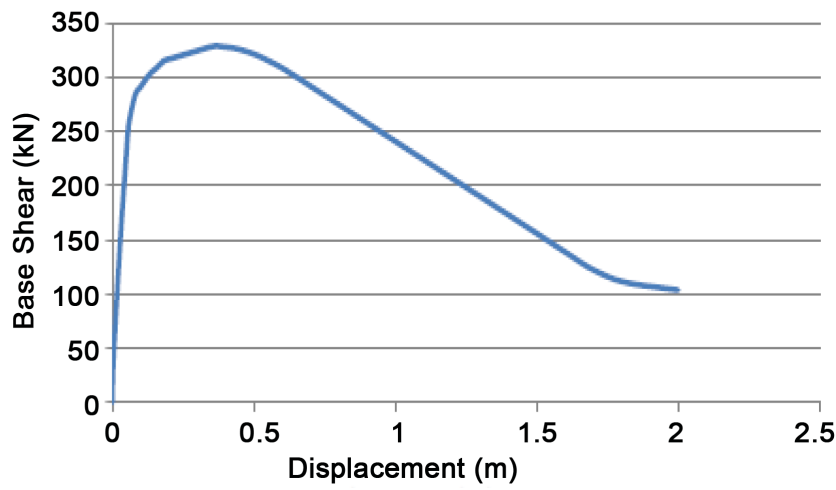

Figure 5. Pushover curve for 5-storey building using 3000 and 2500 psi concrete strength. 

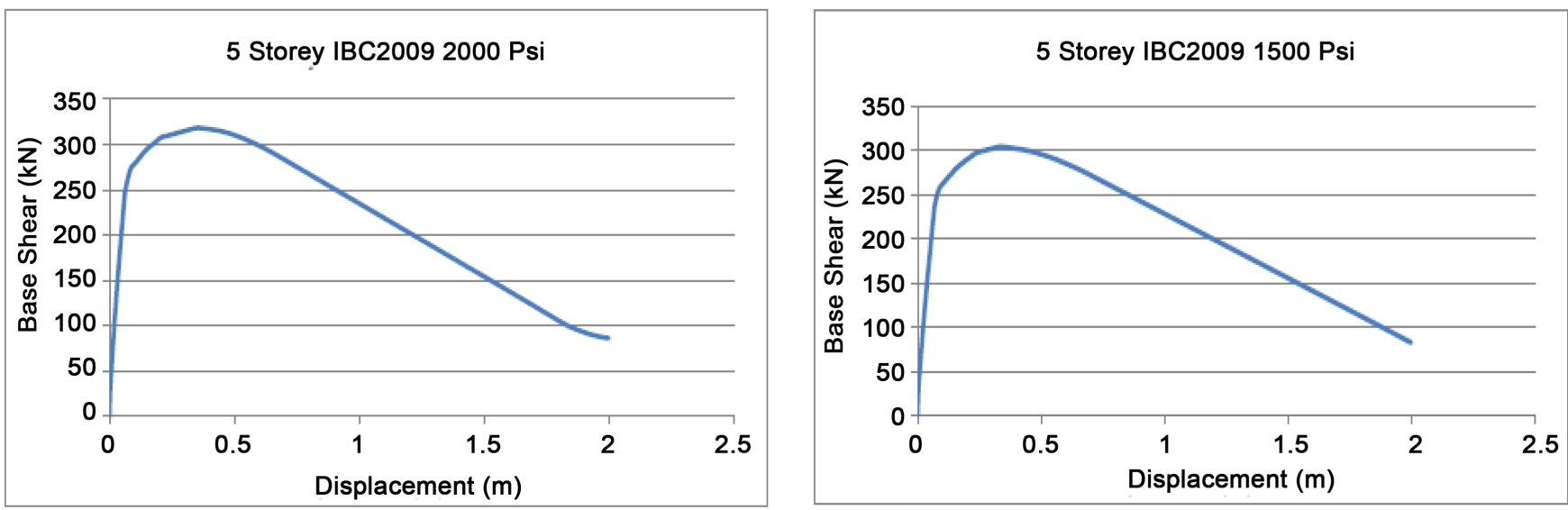

Figure 6. Pushover curve for 5-storey building using 2000 and 1500 psi concrete strength.

From these pushover curves and the tables, it can be noticed that the base shear is decreasing by decreasing the concrete strength but the displacement at point " $D$ " is increasing whenever the concrete strength is decreasing.

\subsection{Plastic Hinges Distribution for 5-Storey Building}

In SAP2000, the nonlinear behavior of beams and columns is represented by assigning concentrated plastic hinges at member ends where flexural yielding is assumed to occur. Flexural characteristics of beams are defined by moment-rotation relationships assigned as moment hinges at beam ends. A three-dimensional interaction surface with five equally spaced axial force-bending moment interaction diagrams and a momentrotation relationship are defined to represent the flexural characteristics of plastic hinges at column ends, and plastic hinges can be easily assigned in SAP 2000 autohinge assignment according to FEMA 356 [5] for columns and also for beams.

From the model we can obtain the main values which are the Immediate Occupancy (IO), Life Safety (LS), Collapse Prevention (CP) and initial failure (D) by increasing the lateral load step by step so we can indicate the base shear and the displacement for each value from the step number. Each color on the plastic hinge location will change according to the stage that the hinge reaches, as shown in the Figures 7-12.

\section{Discussion of Results}

1. For the 5-storey building, model it was noticed that the plastic hinges start to occur in the beams in earlier steps and none of the plastic hinges occur in the columns. But in the 15, 20 and 30-storey buildings plastic hinges start to occur in the beams in earlier steps and at the columns in later steps, which satisfied the weak beam-strong column criteria, more details can be found in reference [6].

2. For the 5-storey building, from pushover curves and tables it can be noticed that the base shear is decreasing by decreasing the concrete strength but the displacement at point " $D$ " is increasing whenever the concrete strength is decreasing for all different concrete strength, i.e., 4000 psi, 3500 psi, 3000 psi, 2500 psi, 2000 psi and 1500 psi. Also 

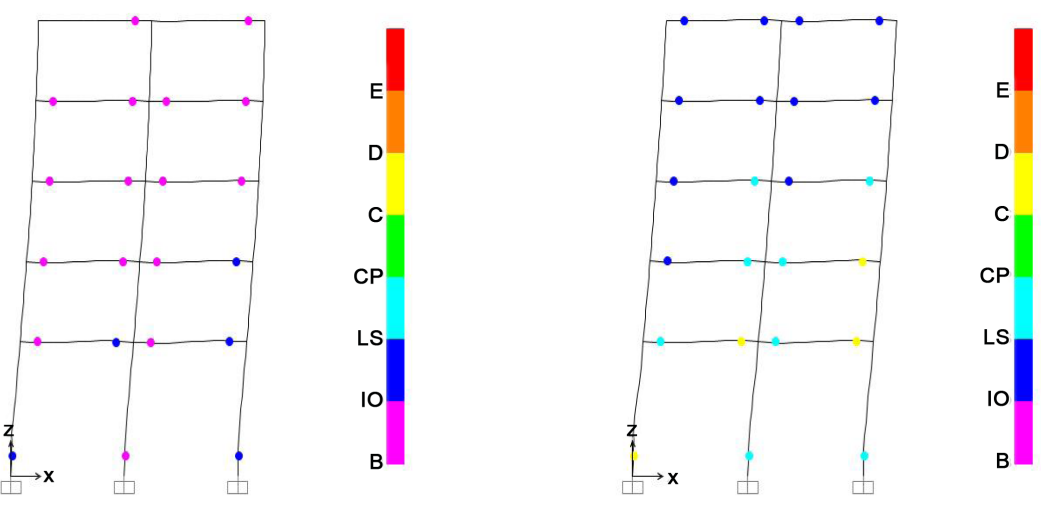

Figure 7. Distribution of hinges in 5-storey building using 4000 psi concrete strength, step 7 (IO) left and step $20(\mathrm{CP})$ right side.
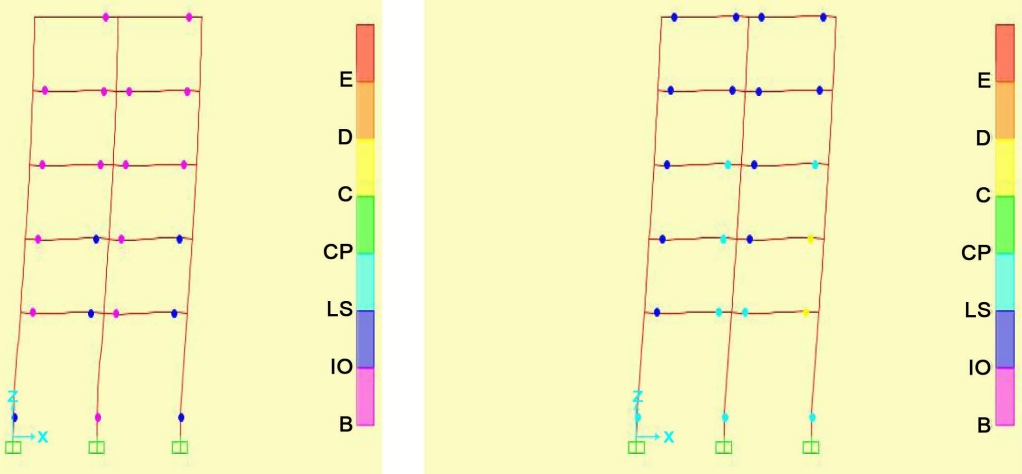

Figure 8. Distribution of hinges in 5-storey building using 3500 psi concrete strength step 7 (IO) left and step 19 (CP) right side.
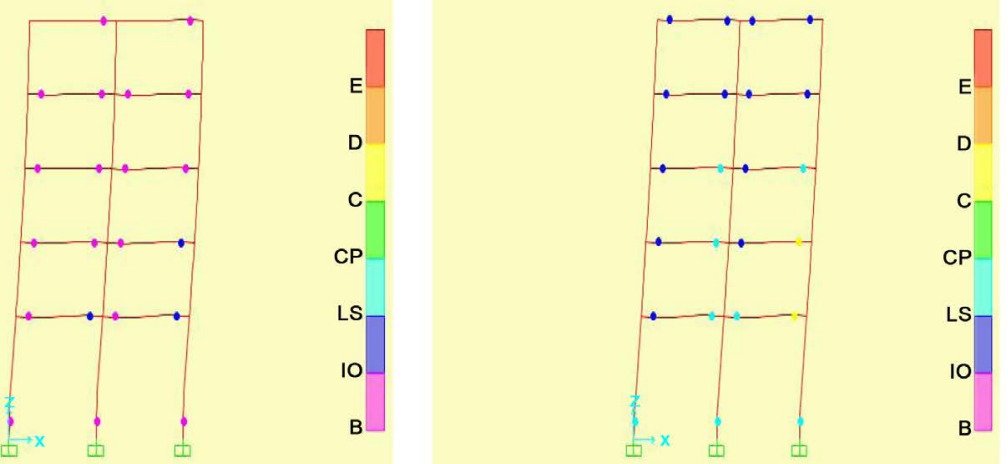

Figure 9. Distribution of Hinges in 5-storey building using 3000 psi concrete strength, step 8 (IO) left and step 20 (CP) right side. 

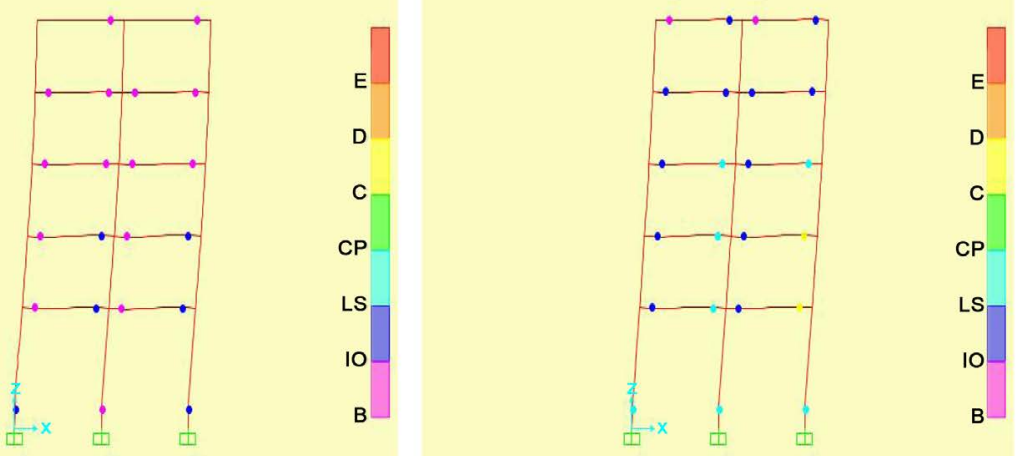

Figure 10. Distribution of hinges in 5-storey building using 2500 psi concrete strength, step 8 (IO) left and step $19(\mathrm{CP})$ right side.

Deformed Shape (Push)-Step 8

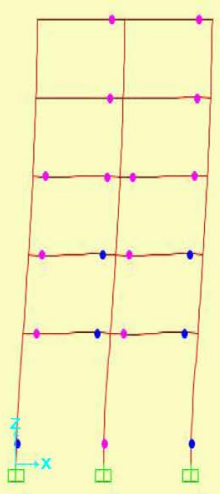

$\cdot$

Deformed Shape (Push)-Step 18

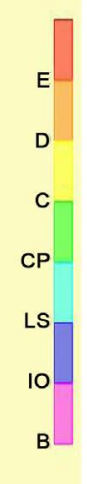

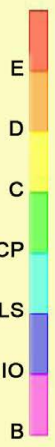

Figure 11. Distribution of hinges in 5-storey building using 2000 psi concrete strength, step 8 (IO) left and step $18(\mathrm{CP})$ right side.

$\int$ Deformed Shape (Push)-Step 7

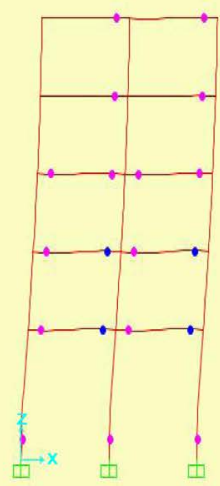

$\cdot$

I Deformed Shape (Push)-Step 18

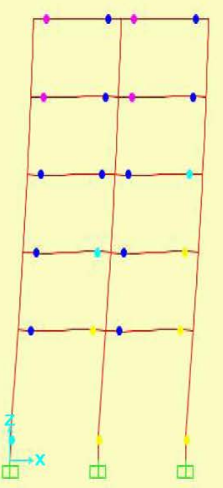

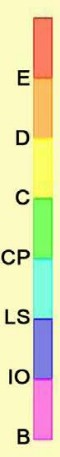

Figure 12. Distribution of hinges in 5-storey building using 1500 psi concrete strength, step 7 (IO) left and step $18(\mathrm{CP})$ right side. 
it was noticed that the failure occurred at the $3 \mathrm{rd}$, 4 th and 5th floors for all cases except for 2000 psi and 1500 psi the failure was at 2nd and 3rd floors, more details can be found in reference [6].

3. For 15-storey building, it was noticed that the base shear decreases when the concrete strength decreases and the displacement at point " $D$ " is increasing whenever the concrete strength is decreasing for all different cases, i.e.,4000 psi, 3500 psi, 3000 psi, $2500 \mathrm{psi}, 2000 \mathrm{psi}$ and $1500 \mathrm{psi}$. Also it was noticed that the failure occurred at the 4th and 5th floors for all cases except for $1500 \mathrm{psi}$ the failure was at the 3rd, 4th and 5th floors, more details can be found in reference [6].

4. For 20-storey building, it was noticed that the base shear decreases when the concrete strength decreases and the displacement at point " $D$ " is increasing whenever the concrete strength is decreasing for all different cases, i.e., 4000 psi, 3500 psi, 3000 psi, $2500 \mathrm{psi}, 2000 \mathrm{psi}$ and $1500 \mathrm{psi}$. Also it was noticed that the failure occurred at the 7th and 8th floors for all cases except for 1500 psi the failure was at 6th, 7th and 8th floors, more details can be found in reference [6].

5. For the 30-storey building, it was noticed that the base shear decreases when the concrete strength decreases and the displacement at point " $\mathrm{D}$ " is increasing whenever the concrete strength is decreasing for all different cases, i.e.,4000 psi, 3500 psi, 3000 psi, 2500 psi, 2000 psi and 1500 psi. Also it was noticed that the failure occurred at the 7th and 8th floors for $4000 \mathrm{psi}, 3500 \mathrm{psi}$ and $3000 \mathrm{psi}$, whereas failure occurred at 4th, 5th, 6th and 7th for 2500 psi and 2000 psi. But at 1500 psi failure occurred at the 1st, 2nd, 3rd, 4th, 5th and 6th floors, more details can be found in reference [6].

6. Comparison between the reduction in concrete strength and the percentage of base shear of Collapse Prevention (CP) point reduction is summarized in Table 9-12, and Figure 13, more details can be found in reference [6].

Table 9. Concrete strength \% reduction versus base shear (CP) \% reduction for 5-storey building.

\begin{tabular}{ccc}
\hline \multicolumn{3}{c}{ 5-Storey Building } \\
\hline Concrete Strength Reduction & Concrete Strength \% Reduction & Base Shear (CP) \% Reduction \\
\hline $3500 \mathrm{psi}$ & $12.50 \%$ & $1.35 \%$ \\
$3000 \mathrm{psi}$ & $25 \%$ & $2.61 \%$ \\
$2500 \mathrm{psi}$ & $37 \%$ & $5.40 \%$ \\
$2000 \mathrm{psi}$ & $50 \%$ & $8.43 \%$ \\
$1500 \mathrm{psi}$ & $62.50 \%$ & $12.60 \%$ \\
\hline
\end{tabular}

Table 10. Concrete strength \% reduction versus base shear (CP) \% reduction for 15-storey building.

\begin{tabular}{ccc}
\hline \multicolumn{3}{c}{ 15-Storey Building } \\
\hline Concrete Strength Reduction & Concrete Strength \% Reduction & Base Shear (CP) \% Reduction \\
\hline $3500 \mathrm{psi}$ & $12.50 \%$ & $2.94 \%$ \\
$3000 \mathrm{psi}$ & $25 \%$ & $6.73 \%$ \\
$2500 \mathrm{psi}$ & $37 \%$ & $9.16 \%$ \\
$2000 \mathrm{psi}$ & $50 \%$ & $13.89 \%$ \\
$1500 \mathrm{psi}$ & $62.50 \%$ & $19.23 \%$ \\
\hline
\end{tabular}




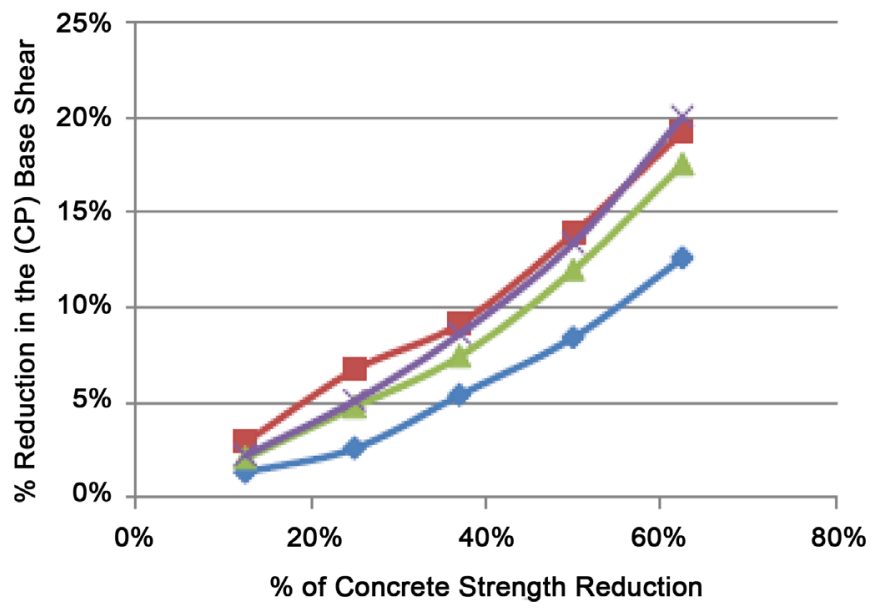

$=5$ Storey Building

$=15$ Storey Building

20 Storey Building

$=30$ Storey Building

Figure 13. Concrete strength \% reduction versus base shear (CP) \% reduction for 5, 15, 20 and 30 -storey building.

Table 11. Concrete strength \% reduction versus base shear (CP) \% reduction for 20-storey building.

\begin{tabular}{ccc}
\hline & \multicolumn{2}{c}{ 20-Storey Building } \\
\hline Concrete Strength Reduction & Concrete Strength \% Reduction & Base Shear (CP) \% Reduction \\
\hline $3500 \mathrm{psi}$ & $12.50 \%$ & $2.10 \%$ \\
$3000 \mathrm{psi}$ & $25 \%$ & $4.78 \%$ \\
$2500 \mathrm{psi}$ & $37 \%$ & $7.44 \%$ \\
$2000 \mathrm{psi}$ & $50 \%$ & $11.96 \%$ \\
$1500 \mathrm{psi}$ & $62.50 \%$ & $17.53 \%$ \\
\hline
\end{tabular}

Table 12. Concrete strength \% reduction versus base shear (CP) \% reduction for 30-storey building.

\begin{tabular}{ccc}
\hline \multicolumn{3}{c}{ 30-Storey Building } \\
\hline Concrete Strength Reduction & Concrete Strength \% Reduction & Base Shear (CP) \% Reduction \\
\hline $3500 \mathrm{psi}$ & $12.50 \%$ & $2.23 \%$ \\
$3000 \mathrm{psi}$ & $25 \%$ & $5.11 \%$ \\
$2500 \mathrm{psi}$ & $37 \%$ & $8.61 \%$ \\
$2000 \mathrm{psi}$ & $50 \%$ & $13.38 \%$ \\
$1500 \mathrm{psi}$ & $62.50 \%$ & $20.02 \%$ \\
\hline
\end{tabular}

\section{Summary}

The recent adoption of seismic code in Abu Dhabi has enhanced the interest of investigation of a seismic safety of existing multistory reinforced concrete buildings. The harsh environment of Abu Dhabi leads to the deterioration of concrete strength of existing buildings. This adds more risk to these buildings. The main objective of this pa- 
per is to evaluate the seismic response of these reinforced concrete frames that deteriorate gradually and to make a comparison between the base shear and the displacement at different stages of earthquake loading.

This study presents typical 5, 15, 20 and 30-storey reinforced concrete frames which have been designed for seismicity according to the recently adopted seismic code in Abu Dhabi, i.e., ACI 318-08 and IBC 2009 codes. The design of the buildings was done by using the computer software SAP 2000 for beams and columns.

Plastic hinges were assigned at the end of columns and beams for the four models. The nonlinear behavior of beams and columns is represented by assigning concentrated plastic hinges at member ends where flexural yielding is assumed to occur. Flexural characteristics of beams are defined by moment-rotation relationships assigned as moment hinges at beam ends. A three-dimensional interaction surface with five equally spaced axial force-bending moment interaction diagrams and a moment-rotation relationship are defined to represent the flexural characteristics of plastic hinges at column ends. Then an incremental lateral load analysis is applied to these frames which is called pushover analysis.

\section{Conclusions}

After designing and detailing the reinforced concrete frames by using ACI 318-08, IBC 2009 code and SAP 2000, non-linear static pushover analyses are carried out to evaluate the structural performance of the frames according to FEMA 356 regulations. The following conclusions can be derived.

1. The base shear decreases when the concrete strength decreases for all different cases, i.e., 4000 psi, 3500 psi, 3000 psi, 2500 psi, 2000 psi and 1500 psi.

2. For low rise building the maximum displacement will not be affected when the concrete strength is deteriorated but it will be highly affected in the medium and high rise buildings.

3. For the 5-storey building model it is noticed that the plastic hinges start to occur in the beams in earlier steps and no plastic hinges occur in the columns. But in the 15, 20 and 30-storey buildings plastic hinges start to occur in the beams in earlier steps and at the columns in later steps, which satisfies the weak beam-strong column criteria.

4. It is recommended to assess the seismic safety for existing multi-storey buildings in Abu Dhabi by using the actual concrete strength especially for buildings near the coastal areas where harsh environment prevails.

5. It is well known that the harsh environment is not the only reason of deterioration of the concrete, inadequate supervision, lack of quality assurance and poor quality control also lead to low efficiency in the concrete strength. It is highly recommended to apply strict regulations for concrete production and construction companies should have strict quality control before casting the concrete.

\section{References}

[1] American Concrete Institute (2008) Building Code Requirements for Structural Concrete (ACI 318-08) and Commentary. Farmington Hills. 
[2] IBC 2009(2009) International Building Code. International Code Council.

[3] Computers and Structures SAP2000 v.15 (2009) Three Dimensional Static and Dynamic Finite Element Analysis and Design of Structures. Berkeley.

[4] Habibullah, A. and Pyle, S. (1998) Practical Three Dimensional Nonlinear Static Pushover Analysis. Structure Magazine.

[5] Federal Emergency Management Agency FEMA 356 (2000) Pre Standard and Commentary for the Seismic Rehabilitation of Buildings.

[6] Sobaih, M.E and Alghazali, A. (2013) Seismic Evaluation of Reinforced Concrete Frames in the Harsh Environment Using Pushover Analysis. MSc. Thesis, Faculty of Engineering \& Applied Sciences, ALHOSN University, Abu Dhabi.

Submit or recommend next manuscript to SCIRP and we will provide best service for you:

Accepting pre-submission inquiries through Email, Facebook, LinkedIn, Twitter, etc. A wide selection of journals (inclusive of 9 subjects, more than 200 journals)

Providing 24-hour high-quality service

User-friendly online submission system

Fair and swift peer-review system

Efficient typesetting and proofreading procedure

Display of the result of downloads and visits, as well as the number of cited articles

Maximum dissemination of your research work

Submit your manuscript at: http://papersubmission.scirp.org/

Or contact ojce@scirp.org 